\title{
Big History in the Ecuadorian Educational System: Theory, Practice, and Public Policies of Environmental Education
}

Javier Collado Ruano

National University of Education, Ecuador

\begin{abstract}
The main objective of this paper is to describe two eco-pedagogical experiences developed with the Environmental Education Program of Educator, using Big History as theoretical framework. A transdisciplinary methodology is used to integrate scientific knowledge with ancestral wisdom, in order to combine an ecology of epistemes. Hence, the study reflects about the intercultural, plurinational, and multiethnic nature of the Ecuadorian citizenship to understand the environmental practices of those ancient worldviews. As result, the article reflects about the theory, practice, and public policies of the Environmental Education Program 'Tierra de Todos' developed by the Ministry of Education in Ecuador. In harmony with the Ecuadorian's Constitution of 2008, that recognized the Rights of Nature, this program has been implemented in all the Ecuadorian Educational System to raise environmental awareness and to restore the ecosystems. This juridical framework is based in the Good Living, a philosophical and political worldview of kiwicha indigenous peoples of Andean Region, where human beings are interconnected with our planet Earth and the whole cosmos. As the main conclusion, the Environmental Education Program seeks to bio-literate citizens to face the complex civilizing challenges of the Anthropocene, by teaching how to feel-think-act in harmony with the co-evolutionary processes of nature.
\end{abstract}

\section{Keywords}

Anthropocene, Big History, Ecuador, Environmental Education, Global Change, Intercultural, Transdisciplinary.

Correspondence | Javier Collado Ruano, javiercolladoruano@gmail.com

Citation | Collado Ruano, J. (2019) Big History in the Ecuadorian Educational System: Theory, Practice, and Public Policies of Environmental Education . Journal of Big History, III(2); 83 - 100.

DOI | http://dx.doi.org/10.22339/jbh.v3i2.3250

\section{Introduction to the Anthropocene and the
Global Change}

In ecent years, the term 'Anthropocene' has become an important topic in scientific, philosophical, and academic debates. Scientists divide the history of our planet into epochs, we are currently living in the Holocene epoch, a name given to the post-glacial geological period of the past ten to twelve thousand years. However, there is a global debate questioning the huge ecological footprint left by humankind on the Earth (Wackernagel \& Rees 1996). The biologist Eugene Stoermer and the Nobel winning chemist Paul Crutzen advanced the term 'Anthropocene' in 2000. It has since gained acceptance as a new geological period characterized by the influence of human behavior on Earth's atmosphere. Using atmospheric carbon dioxide $\left(\mathrm{CO}_{2}\right)$ concentration as a simple indicator to track the pollution acceleration, many researchers have proven that our human activities have experienced a great explosion with significant consequences for Earth System functioning. According to Steffen, Crutzen, and McNeil (2007), the Anthropocene began around 1800 with the onset of industrialization, the central feature of which was the enormous expansion in the use of fossil fuels. The concept emphasizes the influence of humankind in global geology and ecology, where human actions have a drastic effect on the Earth System. 


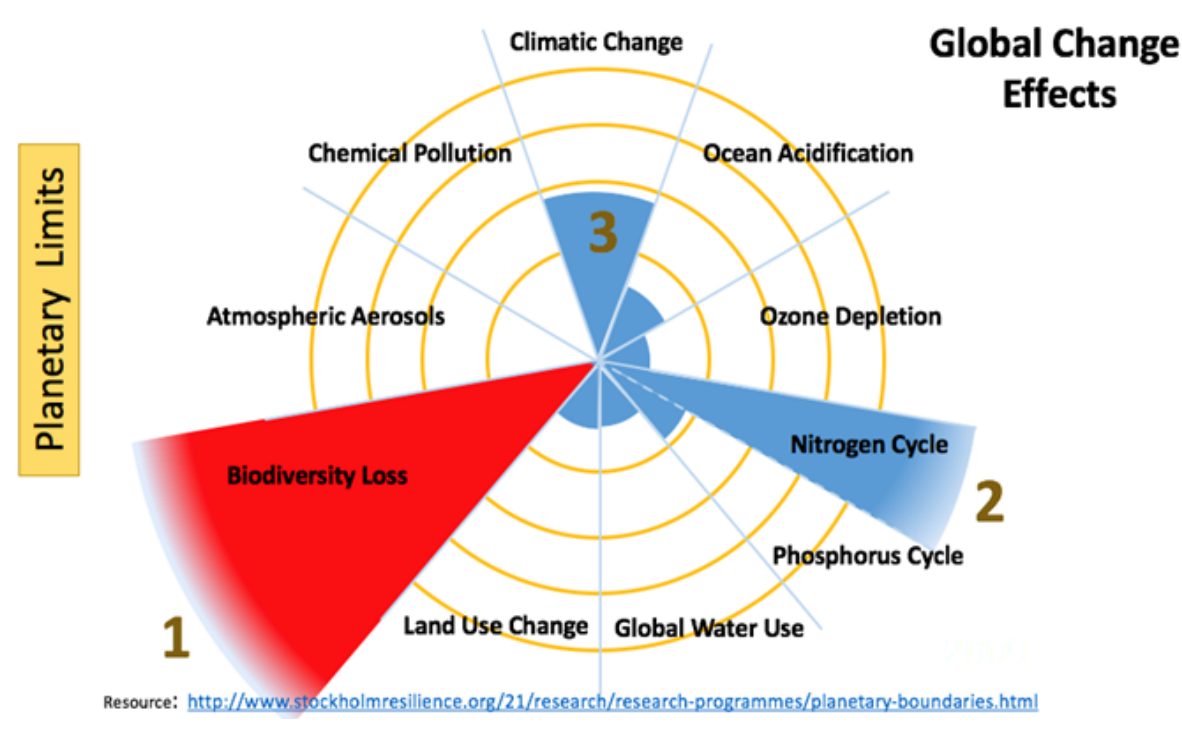

Figure 1. Global Change Effects. Resource: Stockholm Resilience.

the ecosystems' geography around the globe, contributing to global change and leaving a huge ecological footprint (Wackernagel \& Rees 1996).

As a result, the environmental activism began o emerge in nternational institutions in 1972, with the 'United Nations Conference on Human Environment' held in Stockholm. In 1977, the UNESCO and the UNEP organized the 'Intergovernmental Conference on Environmental Education' in Tbilisi (Georgia, URSS), to expand its political-educational scope. According to the Thilisi Final Report, "Environmental Education should

As explained in Figure 1, the term global change refers to multidimensional changes on planetary scale that occur in the Earth System. This encompasses problems such as biodiversity loss, nitrogen cycle, climate change, phosphorus cycle, land use change, global water use, ocean acidification, ozone depletion, chemical pollution, atmospheric aerosols (among other inter-systemic and planetary problems concerning to environment, health, economy, energy, transportation, communication, urbanization, sea level rise, food, overfishing, and use of natural resources) (Bowman et al., 2009). As a whole, Earth acts as a meta-system constituted by bio-physical systems that interact with each other, giving place to the prevailing global environmental conditions. Solutions cannot be researched independently because all the socio-ecological problems of today's world are interdependent. Many Earth System scientists have concluded that humanity has harvest natural resources in a transcendental manner (Leff, 2002; Malo, 2015). Our socioeconomic systems conceive nature as an object that provides unlimited raw materials to industrial production models (Falconí 2014). According to Carson (1962), Schumacher (1973), and Kellert (2005), capitalism has transformed help raise awareness of the economic, political and ecological interdependence of the modern world in order to accentuate the spirit of responsibility and solidarity among nations." (UNESCO, 1978, p.12). After the first stage of conceptualization, environmental education achieved important social and political commitments during the 1980s. The creation of the 'Commission on Environment and Development' in 1983 was a key event to develop a holistic vision on the environmental problems of our planet. After several years, the commission delivered its first report in 1987, with the title 'Our Common Future.' This document identified the ecological limits for economic growth in industrialized societies, establishing direct links between poverty reduction, gender equity, and redistribution of wealth with environmental conservation strategies. The document was the first to define the term 'sustainable development' as the process that "meets the needs of the present without compromising the needs of future generations" (United Nations, 1987).

The final recommendations of the Tbilisi Conference confirmed the inseparable link between the problems of civilization development and 
environmental education. Although this definition of sustainable development is a bit vague and imprecise, environmental educators began to use it to expand a debate about planetary sustainability that still goes on today in formal and non-formal education (Arboleda \& Paramo 2014; Teitelbaum 1978). Regional and international cooperation is a constant in the document to solve the planetary crisis that represents the ecological catastrophe created by humans. Experts recommended rethinking the industrial growth model based on the repudiation of gross domestic product (GDP) as a useful indicator to measure social progress (Stiglitz, Sen \& Fitoussi 2010). Depending on those GDP economic-mercantile indicators, natural resources such as water, air or land, are not taken into account to measure social development (Neaman, Otto \& Vinokur 2018). They are also obsolete because they exclude environmental health as an essential requirement for preservation, conservation, and proliferation of life (Riechmann \& Tickner 2010).

Paradoxically, these natural resources are sacred in many ancestral views of indigenous people from all over the world. In many towns of Abya Yala (original name for Latin America), Mother Earth or Pachamama is conceived as a dynamic organism that is alive: rivers are its veins, mountains are its skin, forests and jungles are its fur, plants are spirits... According to some ancestral worldviews from the Andean Region, Nature provides biomimetic lessons in survival, resilience, and coevolution, as well as sophisticated diversification strategies that have been proven in a constant process of trial and error developed during 3.8 billion years. Then, designing regenerative cultures with the inherent wisdom of nature is the most efficient way to re-establish a creative fit between humanity and nature (Collado 2018).

For this reason, the Environmental Education Program 'Tierra de Todos', developed by the Ministry of Education of Ecuador, has used the Big History as theoretical framework to raise awareness in the whole educational system. As historian David Christian
(2010) proposed, the Big History integrates the history of the universe, Earth, and life along the history of mankind, in order to understand much better our socio-ecological reality. While science gives us light and specific data to many questions about our external physical cosmos, the ancestral wisdom allows us to explore our inner spirituality (free of religious dogmas). For example, the Kiwicha worldview uses medicinal and sacred plants to feel-think-act harmonically with our planet Earth, also known as Pachamama for these indigenous peoples. That is why the Environmental Education Program combines a transdisciplinary approach within scientific knowledge and ancestral wisdom to face the unsustainable challenges of our planet. Under this view, the 2008 Ecuadorian Constitution recognized Nature's Rights at the same legal status as Human Rights. This Constitution is a clear example of intercultural dialogue, where the epistemes of western modern science converged with ancestral wisdom of different ethnic peoples that make up the complexity of this Andean country (Acosta 2013; Tortosa 2009).

In this historical context, this article reflects about two eco-pedagogical experiences using Big History as theoretical framework in the Ecuadorian Educational System to raise environmental awareness. The Big History integrates an academic dialogue to unify the history of the cosmos, the history of our planet Earth, the history of life, and the humankind history (Christian 2010; Grinin, Korotayev \& Rodrigue, 2011; Spier 2011). For this reason, the author explains two different educational experiences that used Big History to reinforce the Environmental Education Program in Ecuador: 1) as professor in the National University of Education (UNAE), in the subject 'Education, Science, and Good Living, and 2) as special advisor of the Ministry of Education, with the implementation of green spaces in schools of Primary and Secondary Educational System. In sum, this article makes an introduction to the global change effects and the huge ecological footprint of the Anthropocene. Then, the paper analyzes the theory, practice, and public policies of the 
Environmental Education Program. In addition, the multi-ethnic, plurinational, and intercultural nature of the Ecuadorian citizenship is described to understand the ecological consciousness and environmental practices of these ancient worldviews. Finally, it concludes with some reflections about how to regenerate our planet with environmental policies.

\section{Big History in Ecuadorian Educational System: Theories and Practices in the Environmental Education Program}

To speak about theories, practices, and public policies of Environmental Education in Ecuador is to emphasize that it is a pioneer country in the constitutional recognition of the Rights of Nature. It is the only country in the world that establishes nature as a subject of law. This legal advancement is a conquest of the indigenous peoples that, with their different ethnic groups and nationalities, has managed to capture their ancestral worldviews in the Constitution. According to political scientist Acosta (2013), 'Buen Vivir' (Good Living) is a political and philosophical proposal based on Sumak Kawsay, an ancestral Kichwa worldview that understands human beings as an integral and interdependent part of their social and natural environment. This worldview is also known as Suma Qamaña for the Aymara peoples of Bolivia, Peru, Chile, and Argentina (Tortosa 2009). Therefore, Good Living is the essence of Amerindian indigenous philosophy, which is characterized by its biocentric, intercultural, plurinational, and decolonial vision (Walsh 2009). This approach is present throughout the Ecuadorian Constitution of 2008 (Simon 2013), and in its' seventh chapter recognized Nature's rights as follows:

Art. 71. - Nature or Pacha Mama, where life is reproduced and carried out, has the right to have its existence and the maintenance and regeneration of its life cycles, structure, functions and evolutionary processes fully respected. Every person, community, town or nationality may demand from the public authority the fulfillment of Nature's rights. To apply and interpret these rights, the principles established in the Constitution will be observed, as appropriate.

Art. 72. - Nature has the right to restoration. This restoration will be independent of the obligation of the State and natural or legal persons to indemnify individuals and groups that depend on the affected natural systems. In cases of severe or permanent environmental impact, including those caused by the exploitation of non-renewable natural resources, the State will establish the most effective mechanisms to achieve restoration, and will adopt the appropriate measures to eliminate or mitigate the harmful environmental consequences.

Art. 73. - The State will apply precautionary and restriction measures for activities that may lead to the extinction of species, destruction of ecosystems or the permanent alteration of natural cycles. The introduction of organisms and organic and inorganic material that can permanently alter the national genetic heritage is prohibited.

Art. 74. - Individuals, communities and nationalities will have the right to benefit from the environment and the natural resources that allow the Good Living or Sumak Kawsay. The environmental services will not be susceptible of appropriation; its production, provision, use and exploitation will be regulated by the State (Asamblea Nacional 2008).

As a whole, the Constitution of 2008 designs the comprehensive exercise of state tutelage over the environment and the co-responsibility of citizens in its preservation, which must be articulated through a decentralized national system of environmental management. That is why public policies for the 
restoration of nature are oriented towards intersectorial and participatory management of shared responsibility. Town halls are the guarantors of deploying (eco)efficient mechanisms in their respective management areas, but private industrial sectors must also assume their role in accordance with socio-environmental welfare. In this way, an interinstitutional governance is proposed that replaces the anthropocentric vision of the traditional economy, and it seeks to consolidate a biocentric conception that restores and regenerates ecosystems. In total, the Ministry of Environment of Ecuador (MAE, 2015) estimates that there are some 4,800 species (fish, amphibians, reptiles, birds, and mammals) throughout the country. That is why Ecuador is known as a 'megadiverse' country.

Regarding its cultural diversity, Ecuador is characterized as a multi-ethnic, plurinational, and intercultural country, where different peoples coexist from a long time ago. According to data from the 2010 Census (INEC, 2010), the 13 million of inhabitants of Ecuador self-identify according to their customs and traditions in 45 ethnic groups distributed by coast, highland, amazon, and insular regions. Constitution's Article 1 reminds us that "Ecuador is a constitutional State of rights and justice, social, democratic, sovereign, independent, unitary, [multi-ethnic], intercultural, plurinational and secular. It is organized in the form of a republic and governs in a decentralized manner." This ethnic diversity is grouped into 14 nationalities and 20 cultural groups, who speak 14 languages throughout the territory (MCP, 2009). The flourishing of intercultural citizenship entails the overcoming of the historical exclusion imposed by coloniality (Mignolo 2001; Quijano 2000). In short, the will of the Constitution is national unity through the democratic and transdisciplinary recognition of multi-ethnic, plurinational, and intercultural richness (Walsh 2009). But what do the prefixes multi-, pluri-, inter-, and trans- mean in those social, political, cultural, and epistemic fields? According to Nicolescu's (2008) definitions, there are important differences:

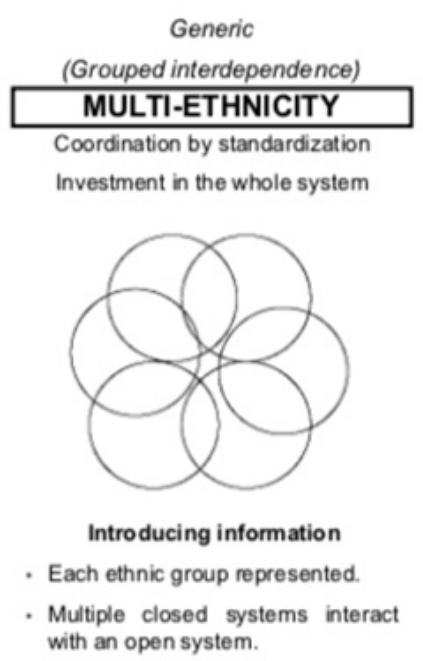

Figure 2. Multi-ethnicity. Graphic by Javier Collado Ruano.

ethnic nature of its population, which means that there are 45 ethnic groups that adopt collaborative relationships with common objectives, but each one continues to maintain its own cultural, linguistic, historical, and artistic characteristics.

Pluri-nationality: the pluridisciplinary approach studies an object by several disciplines at the same time,

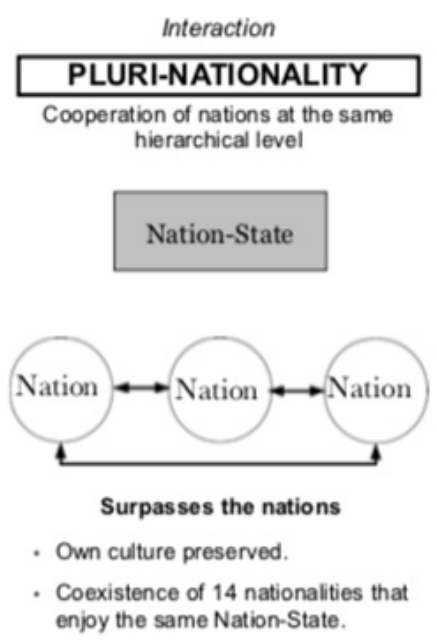

Figure 3. Pluri-

nacionality. Graphic by Javier Collado Ruano. located generally at the same hierarchical level. The pluridisciplinary approach goes beyond the disciplines through a disciplinary interaction or cooperation, where the own methods of each one are conserved, and whose purpose continues inscribed in the disciplinary research structure (Nicolescu 2008). The Constitution of Ecuador recognizes the plurinational nature 
of its population, which means that the NationState of Ecuador is composed for the coexistence of 14 nationalities that enjoy the same legal status. The plurinational approach surpasses the nationalities through an interaction or cooperation between the 14 nations, where each nation retains its geographical spaces, cultures, languages, values, and worldviews.

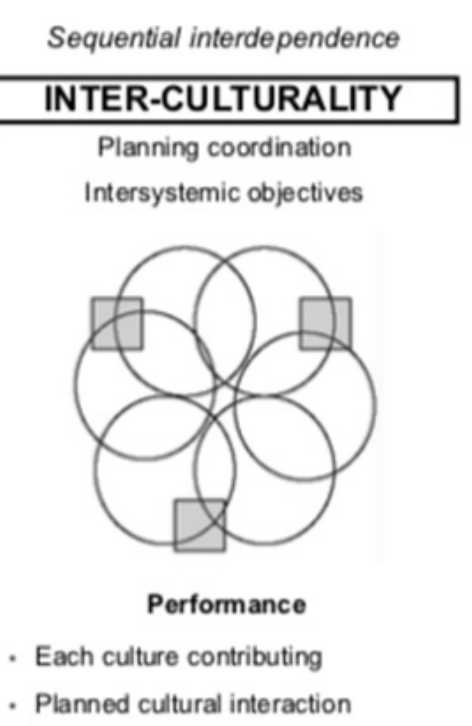

Figure 4. Inter-culturality. Graphic by Javier Collado Ruano.
Inter-culturality: the interdisciplinary approach studies an object of research through the prolonged and coordinated interaction between academic disciplines, leading to the integration of different discourses and the creation of a common conceptual framework and lexicon. The interdisciplinarity forms bridges between the cracks of the disciplinary structures, arriving to formulate a common methodology that transcends the interface of the epistemologies of different disciplines (Nicolescu 2008). The Constitution of Ecuador recognizes the intercultural nature of its population, which means that the 20 Ecuadorian cultures interact in a prolonged and coordinated manner, leading to the integration of different cultural discourses and the creation of a common legal framework. Interculturality forms bridges between cultural worldviews, leading to formulate an opening that transcends the interface of the epistemologies of different cultures.

Transdisciplinary: the transdisciplinary approach studies an object of research through the prolonged and coordinated interaction

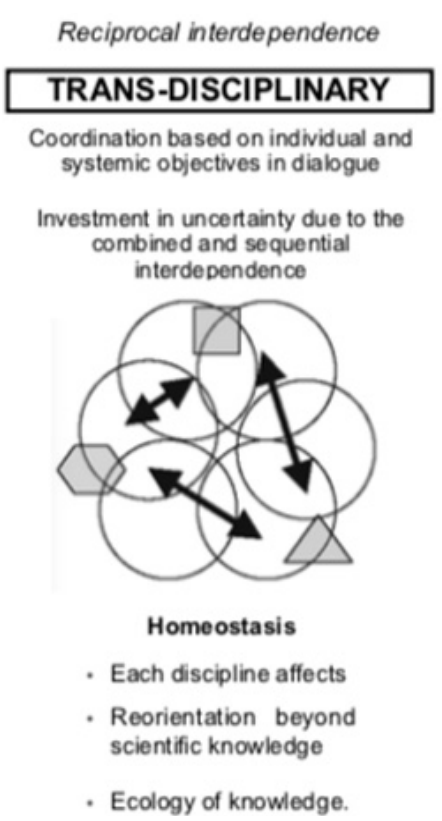

Figure 5. Trans-disciplinary.

Own elaboration. Graphic by Javier Collado Ruano.

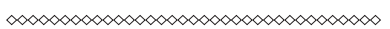

between the s c i e $\mathrm{nt}$ if i c $\mathrm{kn} \mathrm{ow} \mathrm{le} \mathrm{d} \mathrm{g} \mathrm{e}$ of academic disciplines and the wisdom produced outside the academy (arts, spirituality, e $\mathrm{m}$ o $\mathrm{t}$ i o $\mathrm{n} \mathrm{s}$, ancestral wisdom of indigenous peoples, mystical experiences and other dimensions h i s t or i c a $11 \mathrm{y}$ forgotten by the sciences), in a process of reciprocal learning and without hierarchy. The transdisciplinarity develops a general axiomatics that crosses the essence of the disciplines, through an ecology of knowledge that is 'in, between and beyond the disciplines,' in order to achieve the unity of knowledge (Nicolescu 2008).

After some months of discussion, those definitions took shape and the multi-institutional Committee for the Environmental Education Program created strategies, (re)designed the curricula, and implemented actions in Primary and Secondary schools of Ecuador. Henceforth, two eco-pedagogical experiences are described to show how the Big History has been used as a theoretical framework to enrich theory, practice and public policies of Environmental Education.

\subsection{Experience Teaching 'Education, Science, and Good Living' in the National University of Education (UNAE) of Ecuador}

Those definitions to Ecuadorian realities were used during the 2018 course, in the subject 'Education, 
Science, and Good Living, with the students of $1^{\text {st }}$ year of Education in Experimental Sciences of the National University of Education of Ecuador (UNAE). It was very important to contextualize all students into their complex reality to promote a transdisciplinary vision of Big History. This subject used Big History as theoretical framework to raise environmental awareness in the transversal axis of Environmental Education. During the entire academic year, the students used the flipped room methodology to research the main theories of various sciences. In each class, a couple students would explain to the others the main theories within cosmology, astrophysics, astronomy, classic and quantum physics, atmospheric chemistry, geology, biology, ecology, geography, anthropology, demography, sociology, theology, and so on. Pedagogical didactics reinforced their significant learning because they interlinked various epistemes in horizontal way - toward an ecology of knowledge (Santos 2010). In other words, by approaching the Big History from a transdisciplinary approach, students understood much better the interconnections of the humankind with the different levels of reality that co-exist in nature and in the cosmos (Collado 2016). The lessons combined scientific theories with mystical and spiritual experiences, very present in the rituals of shamanism with Ayahuasca and other sacred plants of the Andean region.

Another good example of this transdisciplinary learning of Big History was the visit to the Ingapirca Ruins, an archaeological complex wherein the largest and most ancient ruins in Ecuador can be found.. As the Inca Empire expanded into southern Ecuador, they met Cañari indigenous peoples in the early 16th century. After some confrontations, they decided to settle their differences and live together peacefully. The castle complex is of Cañari-Inca origin; however, its purpose remains unknown. During the visit to Ingapirca, the astronomer Vladimir Peña and the architect Pablo Jara explained to our students the links between astronomy, architecture, ancient cultures, and ancestral worldviews.

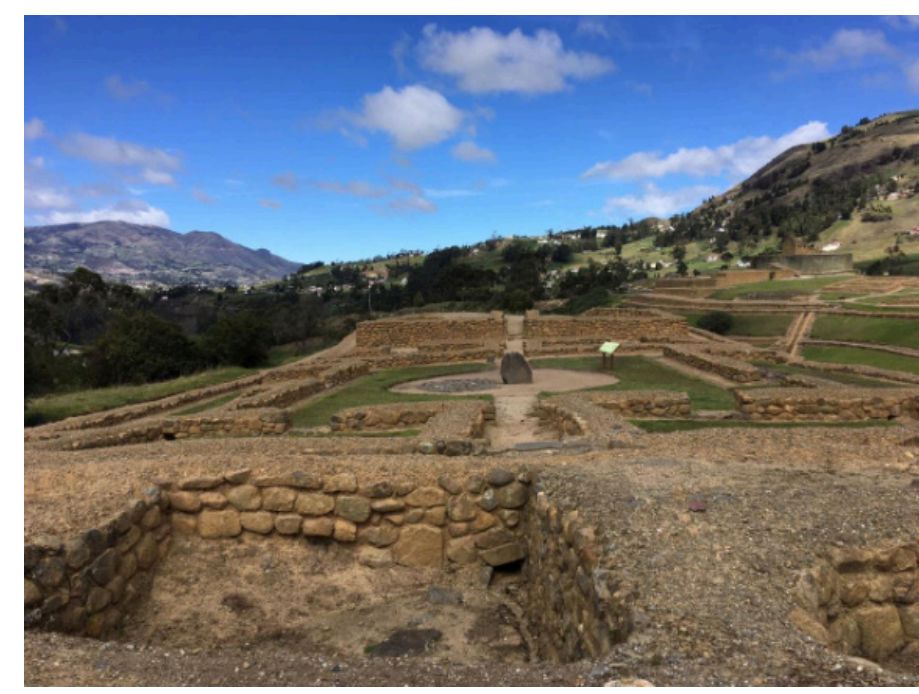

Photo 1. Archeological complex of Ingapirca. Photo by Javier Collado Ruano

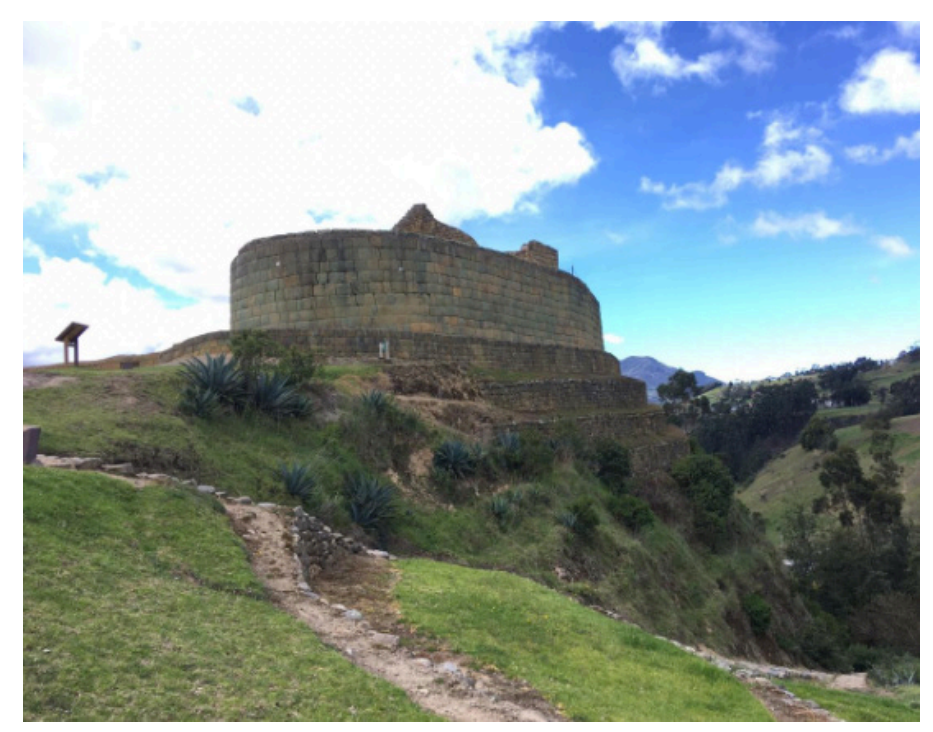

Photo 2. Astrological observatory of Ingapirca. Own resource. Photo by Javier Collado Ruano.

This visit to Ingapirca was made during the commemoration of the World Environmental Education Day, on January $26^{\text {th }}, 2019$. The Ingapirca complex had long been settled by the Cañari and Inca cultures - the same cultures that built the elliptically shaped Temple of the Sun. This was used as atronomical observatory and the stones were carefully positioned in keeping with their beliefs and knowledge of the 


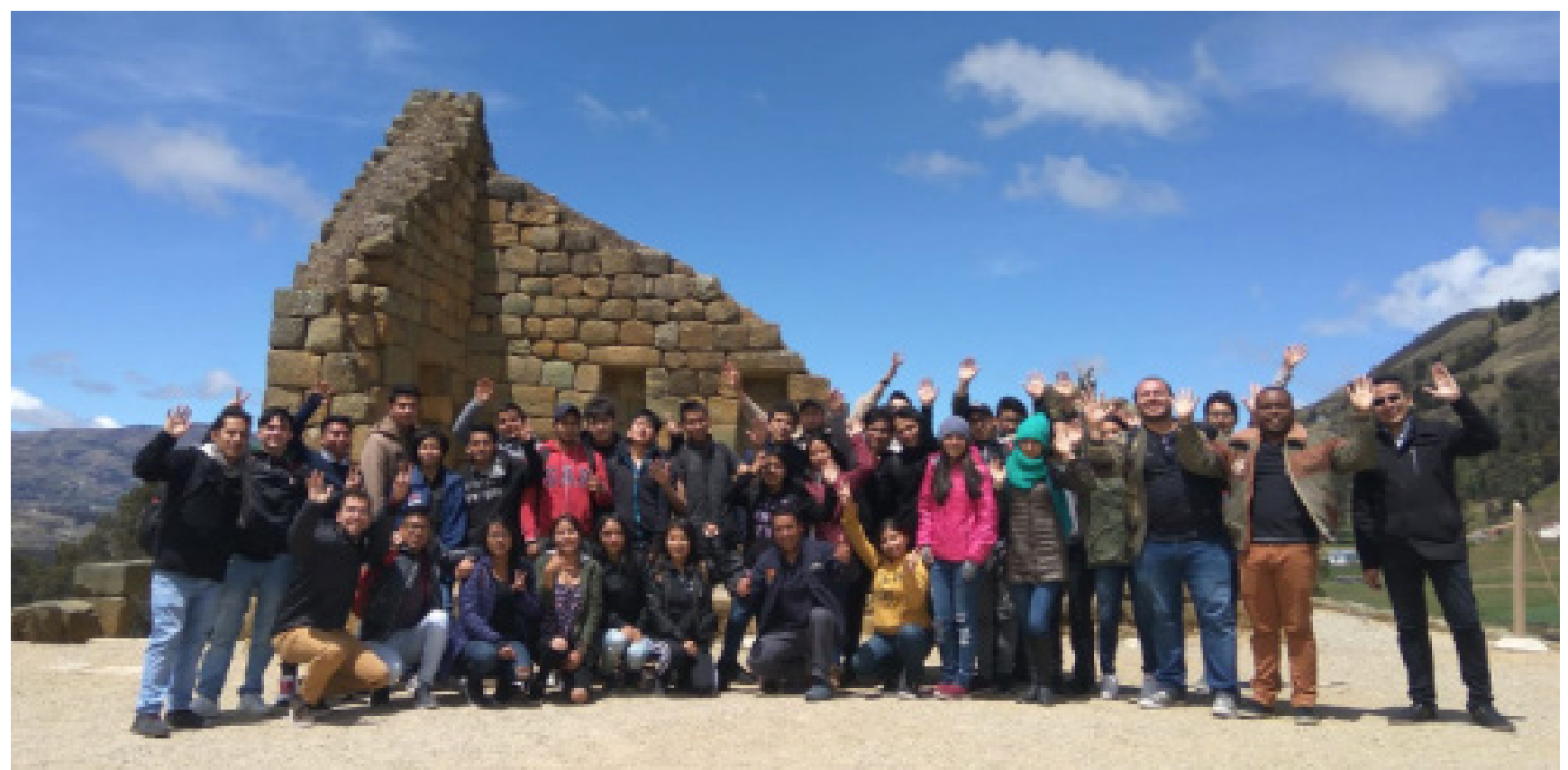

Photo 3. Students of Education in Experimental Sciences visiting Ingapirca ruins.Photo by Javier Collado Ruano

cosmos. Some researches argue that the Temple of the Sun was positioned so that on the solstices, at exactly the right time of day, sunlight would fall through the center of the doorway of the small chamber at the top of the temple (Diaz 2013). As sun and moon worshipers, they built their monuments high in the mountains to be closed to their gods. Those ancient peoples had numerous ritual celebrations at the complex, using fermented drinks to consume during the festivals. This visit made clear to our students the relationship between astronomy, architecture, ancestral wisdom, indigenous worldviews, spirituality, and intercultural beliefs.

Moreover, Big History's scientific theoretical framework was enriched with ancesteral wisdom which provided better understanding of the multiethnic, plurinational, and intercultural complexity of Ecuador. This decolonial and transdisciplinary vision of history integrates and unifies diverse epistemes that are within, between, and beyond the scientific disciplines (Nicolescu 2008). That is, it includes ancestral wisdom, indigenous worldviews, spirituality, arts, emotions, mystical experiences, and other dimensions forgotten in the history of science, especially by the positivist approach. Important human dimensions were excluded because they cannot be measured or quantified by scientific instruments. Paradoxically, facing the challenges of global climate change means rescuing essential human dimensions to propose regenerative cultures and transform our relationship with nature and the whole cosmos. For this reason, my experience as professor in the subject 'Education, Science, and Good Living' has proven that Big History constitutes a perfect theoretical model to enrich the eco-pedagogical practices that Environmental Education Program requires.

In fact, a questionnaire was iven to all the students on the subject 'Education, Science, and Good Living,' a career within Education in Experimental Sciences. Here, they learn pedagogies and didactics about how to became teachers of Physics, Chemistry, Biology, and Mathematics in Primary and Secondary schools of Ecuador. The answers give us their opinion about this theoretical and methodological approach. In total, 
103 students replied with the following highlights:

What science do you like most to learn in the UNAE?

103 responses

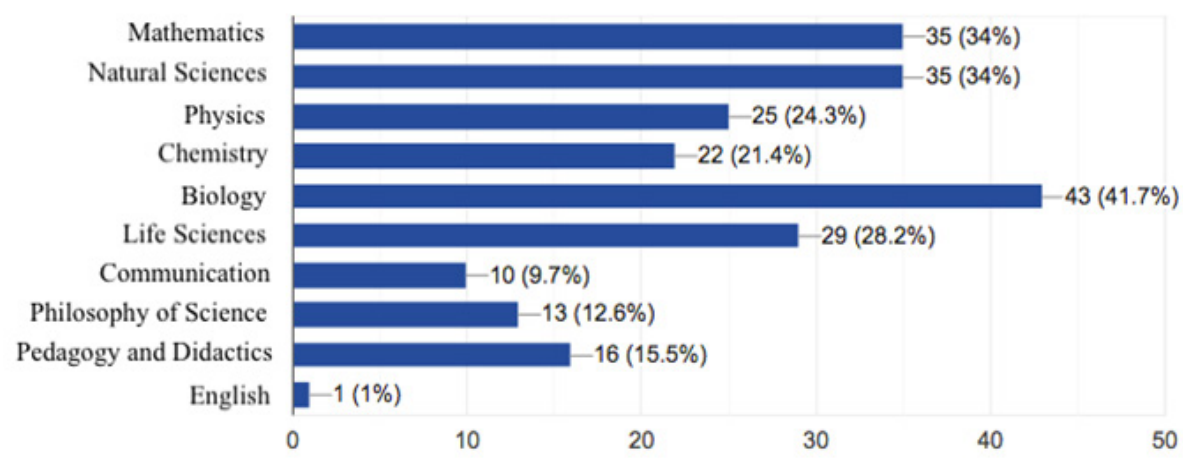

In your opinion, what is the level of importance that learning Big History has in your teacher training?

103 responses

60

55 (

40

20 $15(14.6 \%)$ 20

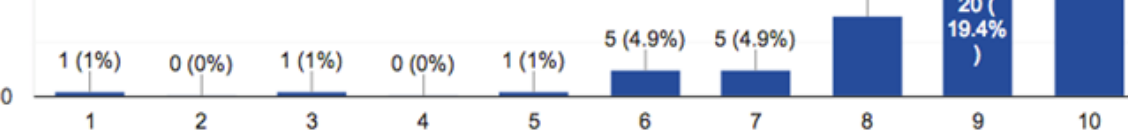

Would you like your university to create scientific and academic events that promote Big History?

103 responses

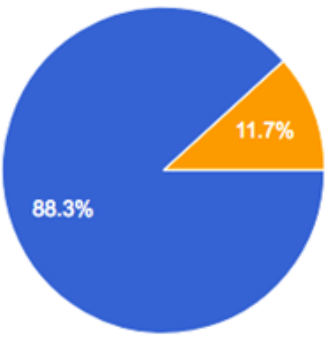

Yes, it is a new way of understanding science and it is necessary to spread it to all audiences

I'm not interested in this way of understanding science

It would be very interesting, but maybe in the next few years 
Would you like the teachers at your university to teach you Big History in your classes?

103 responses

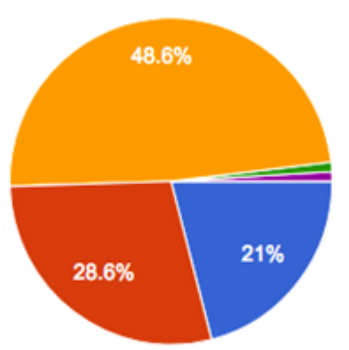

I prefer to study each science separately (positivist approach)

I prefer to study the complexity and interrelations between the different sciences (transdisciplinary approach)

I think it is necessary to have a 'macro' and 'micro' vision at the same time

I think it's too difficult and it's better to work in a traditional way

Yes, I would like it

What epistemological approach do you think is most correct to teach Big History?

103 responses

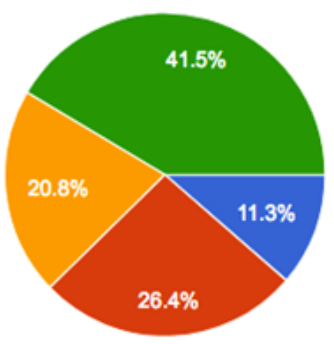

Disciplinary (knowledge is fragmented and studied by sciences that are separated)

Multidisciplinary (it studies the Big History from several sciences but each one keeps his own method)

Interdisciplinary (the different sciences cooperate among them)

Transdisciplinary (ecology between scientific knowledge and ancestral wisdom)

\section{Would you like to participate in the free online courses of Big History Project?}

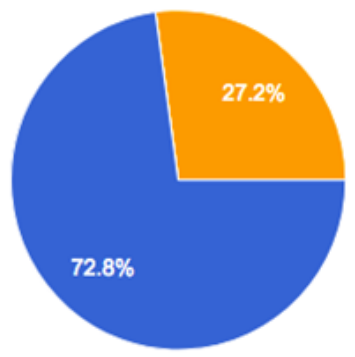

Yes

No

Maybe, but I have some problems to follow the course in English 
In the future, would you like to teach Big History to your students of Primary and Secondary school?

102 responses
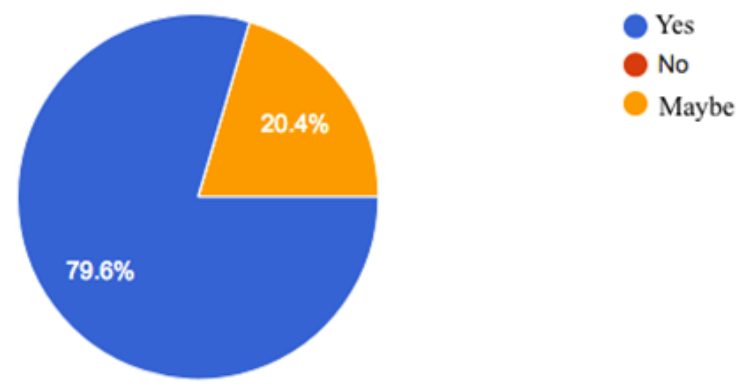

II I couıd teacn big History as a teacner, I wouı пке to aad more кnowieage adout ...

103 responses

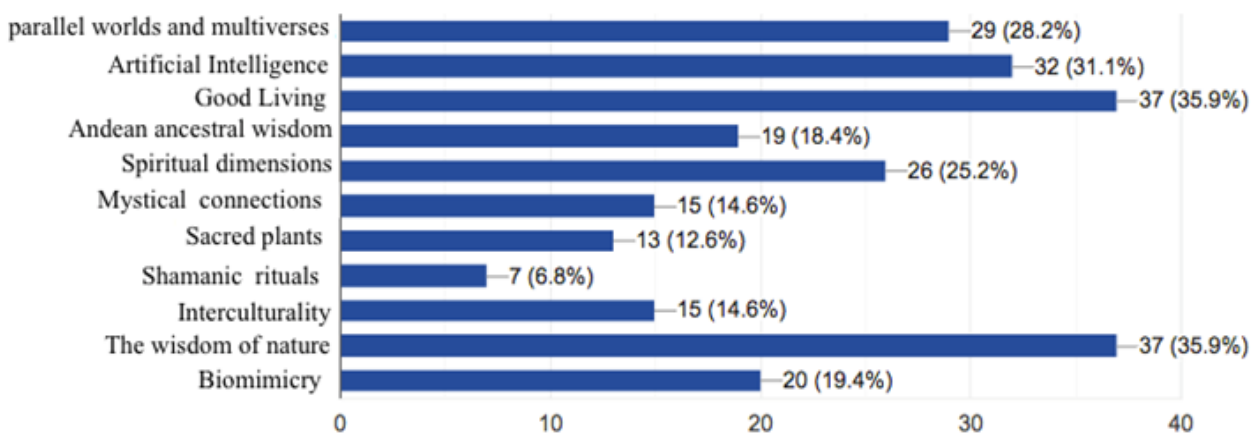

According to the the questionnaire, given to 103 students, their greatest interest lies in studies of cosmology, neuorscience, ecology, and artificial intelligences. They really believe that Big History is very important in their training as future professors of Physics, Biology, Chemistry, and Mathematics. The students also think that our university should promote more academic events on Big History and their professors should teach with a 'macro' and 'micro' vision at the same time. The transdisciplinary approach (41.5\%) is their prefer option to learn Big History, followed by the multidisciplinary (26.4\%), interdisciplinary (20.8\%), and disciplinary (11.3\%) approach. They would like to study in the Big History
Project, but they have some problems with the meaning $s$ as expressed in English. Nearly $80 \%$ of the students would like to teach Big History in primary and secondary schools of Ecuador in the future. Additionally, they would like to gain knowledge about the Good Living philosoph, the wisdom of nature, artificial intelligence, parallel worlds and multiverses, spiritual dimensions, biomimicry, Andean ancestral wisdom, interculturality, mystical connections, sacred plants, and shamanic rituals. I argue here that a transdisciplinary approach to Big History opens a dialogue with ancestral wisdom and intercultural knowledge of Ecuadorian communities. In the Andean region, respecting the ancient worldviews that harmonize 
spiritual and cultural beliefs, has to be the cornerstone to building new scientific knowledge. Then, the decolonization of curricula with those dialogues is an essential process to integrate Big History in Ecuador, but also in many other countries of Latin America and beyond.

\subsection{Experience as Special Advisor on Environmental Education of the Ministry of Education}

From June 2017 until he present, I have had the privilege and the responsibility to act as special advisor of the Ministry of Education, where different specialists have worked together to develop the Environmental Education Program ${ }^{1}$ in Primary and Secondary schools of Ecuador. The program is still in action and the axis of epistemic enunciation of those public environmental education policies has a marked intercultural and transdisciplinary character that includes and integrates scientific knowledge with ancient wisdom of indigenous people (Falconí 2017; Krainer 2012). In this way, the Ministry of Education of Ecuador, in collaboration with other national and international institutions, used a transdisciplinary approach that implies an inter-epistemological dialogue of ancestral worldviews with the natural sciences, social sciences, mathematics, arts, humanities, geosciences, and telecommunications. As shown in Figure 6, the transversalization of the environmental education axis is based on a multidimensional dialogue that germinates both the scientific knowledge and the indigenous wisdom.

According to this multidimensional approach of the Environmental Education, inspired by the Big History vision, my role as special advisor has been focused on three major actions: 1) provide a multidimensional scientific vision on the challenges that we face nowadays with the effects of global climate change, through bibliographic and documented data; 2) guide the educational discourse towards good eco-

1 To read more information visit: https://educacion.gob.ec/ educacion-ambiental/

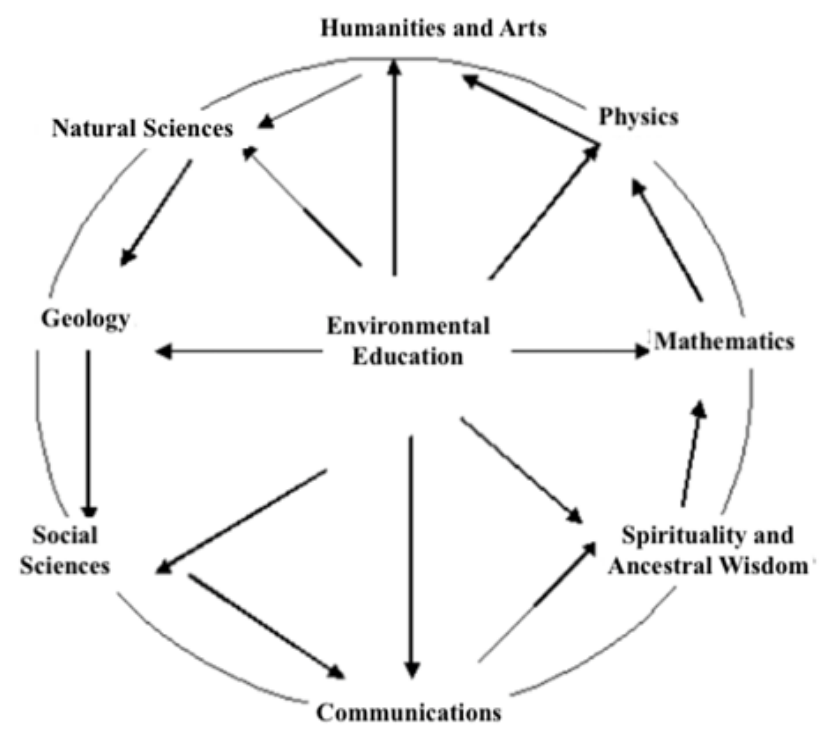

Figure 6. Transdisciplinary dialogue of Environmental Education. Source: Javier Collado Ruano.

pedagogical practices in order to create strategies to implement the Environmental Education Program; 3 ) create two online training courses for more than 165,000 teachers of primary and secondary schools that focuses on environmental quality, maritime awareness, and implementation of environmental projects in educational institutions. The online training program seeks to generate a domino effect in society through the transformation of their socioenvironmental reality. Of course, those actions have been developed along with so many colleagues of the Ministry of Education, the Ministry of Environment, the Marine Institute, the Amazon University (IKIAM), and the National University of Education (UNAE). This committee typically holds a monthly meeting to discuss the various strategies, contents, and visions to be implemented at a multi-level scale. After all this time, many scientific articles, conferences, and movies have been made to disseminate the theories and practices of the Environmental Education Program.

In short, the Environmental Education Program combines the inside and outside dimensions of our human condition at the same hierarchical level. 


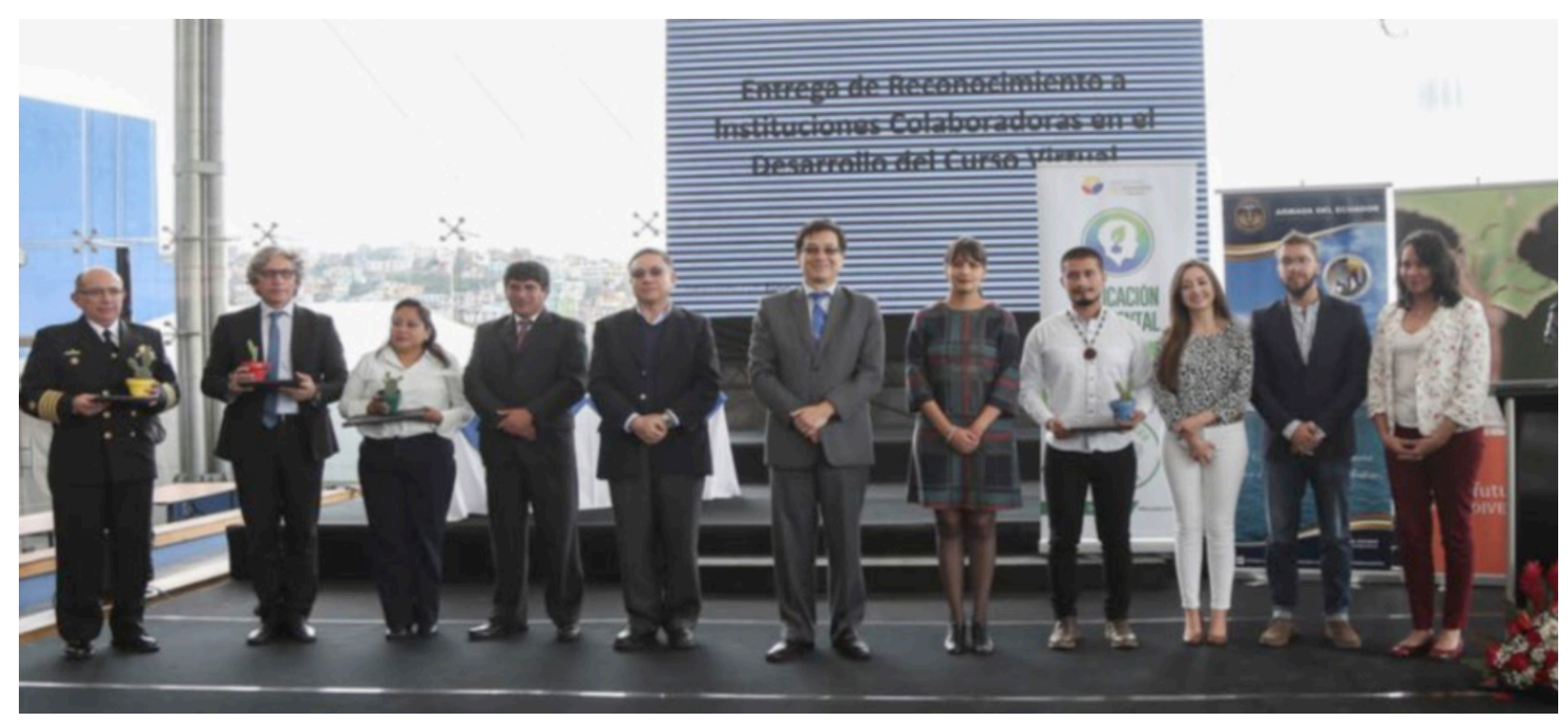

Photo 4. Environmental Education Committee along Minister of Education of Ecuador.

Photo by Javier Collado Ruano.

It means training one's self-awareness, our own spirituality; it means rescuing the ancestral indigenous wisdom and promoting many other rational, logical, perceptive, affective, emotional, rhetorical, poetic, epistemic, creative, artistic, cognitive, and philosophical dimensions of our human condition. By approaching the basics of environmental education in a transdisciplinary way, the teaching-learning processes are significantly enriched, as their training dimensions fertilize each other and lead to new ways of feeling-thinking-acting with Pachamama (Collado 2017). Rooting theoretically, methodologically, and pragmatically the transversalization of environmental education in the Ecuadorian Education System has involved a profound reflection on the theories and practices that have developed - in a multidimensional way - to promote the competencies, skills, and attitudes necessary to face the global change effects (MinEduc 2018a).

Furthermore, Minister Falconí (2017) reflects that we must bet on public policies of environmental education and ecological economy focused on the care of the Earth System and the transformation of the productive matrix (Wassily 1970). Here, the Big History vision helps us to understand the limits of biophysical regeneration of our planet, in order to transform the predatory economic system that guides our civilization. For this reason, facing the global change provoked by capitalism requires transgressing the failed theoretical model of sustainable development established by the academic discourse of technoscience (Leff 2002; Wallerstein 1997). According to Collado \& Malo (2019, p. 339), "while the notion of sustainable development is focused on minimizing the negative impact of humans on the planet, the notion of regenerative development focuses on maximizing the positive impact of human beings on Earth." This regenerative approach represents a qualitative leap in our relations with nature, in harmony with the biocentric vision of restoration embodied in the Constitution of 2008. In this line of thought, (Orr 2002, Pauli 2015, Wahl 2016, and Müller 2018) argue that it is urgent to (re) design regenerative cultures to restore the nature and 
to promote ecological economy and environmental education in public policies. Following this direction, the Equatorial Garden has been implemented in more than 10,000 schools in Ecuador (as described below) and is continuing to advance.

\section{Equatorial Garden: Implementing TiNi's Methodology in Primary and Secondary Schools}

The common denominator of many indigenous and ancestral worldviews is the spiritual and ecological conception that structures their social organizations, which are in harmony and respect with the different forms of life that co-exist in our Mother-Earth. Environmental consciousness is present in many worldviews of Amerindian indigenous people, who understand the sacred attribute of nature as a spiritual connection. Just as no one learns to swim out of water, no one learns to love nature without being in direct contact with it. For this reason, it is not possible to learn Environmental Education without a proper philosophy or methodology. In this direction, the Ministry of Education of Ecuador adopted the 'TiNi' methodology, created in the 90's by Peruvian educator Joaquin Leguía to promote environmental awareness. Nowadays, there are more than 10 countries around the world that have implemented the TiNi methodology. In 2012, the TiNi Methodology was recognized by UNESCO as a good education practice to raise environmental awareness. According to Leguía and Paredes (2016, p.24):

TiNi is a space granted by adults to girls, boys and young people, from half a square meter of land, where with love, they grow life and biodiversity; and in the process they strengthen their knowledge, skills, values, and self-esteem to live in harmony with the environment.

With this educational vision of human training, the Ministry of Education of Ecuador recognized, in 2017, the TiNi methodology as a good educational practice and a fundamental eco-pedagogical resource for the transversalization of the environmental axis in the curricula of primary and secondary schools (MinEduc, 2017). The goal of this methodology is to put girls and boys in regular contact with nature from an emotional approach (Leguia \& Paredes 2016). People from any country can implement the TiNi methodology regardless of their socio-economic or cultural situation, in a rural or urban area, in their schools, homes or communities. With this methodology, students can learn competences, skills and values for sustainable and regenerative management of natural resources. In this process to value nature, culture and identity they learn to develop feelings of affection for all forms of life (MinEduc, 2018b). It is a methodology focused on tackling global change through direct actiontheory learning in the cultivation and restoration of ecosystems. In short, the TiNi methodology has shown that it can be very useful for environmental management, since it favors the care of ecosystems and develops multilevel actions among students and their communities.

The adaptation of the TiNi methodology to the Ecuadorian context is known as the Equatorial Garden, and was made within the public policies framework of the Environmental Education Program 'Tierra de Todos' of the Ministry of Education, in collaboration with other public and privateinstitutions of nationaland international scopes. Here, the Big History theoretical framework is being introduced into schools by the teachers trained in the two online courses described above. The primary objective of Equatorial Garden is to strengthen environmental awareness and promote a regenerative culture throughout the educational community. Through a biocentric approach based on values, ethical orientation, altruism, innovation and education quality, the program seeks to integrate and transversalize environmental education at all school levels as a means to make the Ecuadorian citizens responsible for the social challenges of global change. In this direction, the Program is developed in three 
areas:

1. Implementation of innovative pedagogical methodologies with an affective, playful, practical, intercultural, transdisciplinary, and holistic approach.

2. Strengthening the national curriculum with an environmental approach.

3. Good environmental practices in the education system.

In 2018, the National Education System of Ecuador had a total of 15,365 schools, including primary and secondary levels (MinEduc 2018b). This is a great challenge for the successful implementation of the Program. The Ecuadorian version of TiNi, like every plant transplanted to other lands, has shaped its own idiosyncrasy. The Good Living philosophy has been an important element to this adaptation. On September 2017, the Ministry of Education issued the guidelines for the implementation of this adapted methodology at national level. Just few months later, in June 2018 10,021 schools had inaugurated their own TiNi spaces. In total, more than 2.6 million students and 165,000 teachers benefit from the Equatorial Garden, which already has an extension of more than $1,000,000 \mathrm{~m}^{2}$ for environmental protection and the implementation of environmental education (MinEduc, 2018b). The 'Introductory Guide to TiNi's methodology' was created to explain the importance of respecting the particularities of each school, its territorial environment, and its cultural realities. Good practices of educative intervention are possible now, because teachers materialize the theoretical knowledge offered in classrooms, in a natural space, recognizing students as agents of change that shape their realities day by day with actions that benefit themselves, others and nature.

As a whole, the three action areas of the Program 'Tierra de Todos' have yielded successful and hopeful results. Although it is soon to bring more complete results, the indicators and evaluators of each line of action indicate that the Equatorial Garden has reported multiple benefits. This adaptation of the TiNi's methodology has created an inclusive environment that reinforces the interaction between students, teachers, family and community, generating collective environmental awareness. They all have a transdisciplinary dialogue between scientific theoretical knowledge and ancient community practices. Direct contact with nature has also brought benefits to the health of communities, whose teachinglearning processes have allowed the abstract (theory) to become concrete (practical), and the knowledge and skills acquired have one purpose: environmental care. In the coming years, we expect to obtain broader results that would allow us to better understand the impact of public policies implemented within the framework of the Environmental Education Program 'Tierra de Todos.'

\section{Conclusions to (re)design regenerative cultures}

Both of the eco-pedagogical experiences presented show that using Big History with a transdisciplinary approach in the Environmental Education Program of Educator has been a key factor to promote sustainable and regenerative development for the Earth System. Environmental Education cannot be just about transmitting values and knowledge, but is a creative, constructive and transformative act. Ecuadorian citizenship must learn to develop a continuous, self-conscious dialogue to feel-think-act with their emotional feelings, thoughts, and actions. In fact, sustainable and regenerative development is not only a quantifiable issue in economic terms, but also a human quality of feeling-thinking-acting in harmony with the Pachamama (Collado 2017). For this reason, it is urgent to reinforce public policies aimed at conservation, preservation, and remediation of ecosystems, in order to (re)design regenerative cultures that transform the current civilizatory direction.

As has been presented throughout this work, the public policies developed within the framework of 
the Environmental Education Program 'Tierra de Todos' are aimed at the regenerative development of nature. The great asymmetry and economic inequality that globalization produces translates into planetary unsustainability and puts at risk the existence of future generations, especially in the so-called 'global South.' That is why it is essential to reflect about how to introduce Big History frameworkinto thepublicpolicies on Environmental Education of Ecuador or on other countries. The Environmental Education Program of the Ministry of Education has a transdisciplinary vision in Ecuador, since ancestral wisdom enriches scientific theories with socio-environmental practices that have proven to be sustainable over time. With this vision rooted in public policies of Ecuadorian Educational System it is possible to deepen and improve the human-nature relationship by showing the different contexts, realities, interactions and processes. The partial results presented from the implementation of the program illustrate how necessary it is to continue working on teacher training, strengthening the quality and innovation of school's curriculum, and promoting good environmental practices.

With a biocentric, intercultural, and transdisciplinary vision, the Equatorial Garden is focused on the recovery of the community of life, preservation of a healthy biosphere and, moreover, conceives the Earth System as a sacred duty. According to the Good Living philosophy, the whole planet is an interconnected and indivisible entity. In other words, out planet is an intimately interrelated and interdependent meta-system that requires complex and systemic solutions to achieve sustainable and regenerative development. For this reason, environmental education is conceived in Ecuador as a lifelong process that it should not be confined solely to the school system curriculum, but should be extended to all areas of society. In the Ecuadorian context, environmental education is a transversal element of the curriculum at all schooling levels that includes a deep dialogue with communities where the educational institutions are located. The theory based on the Big History enriches the ancestral practices of environmental education of the communities, and the ancient environmental practices are enriched by the theoretical contributions of the Big History. The Environmental Education Program finds in the Big History theoretical framework a key element that contribute significantly to change the way in which Ecuadorian citizens understand their complex reality. In sum, the theories, practices, and public policies presented in this paper focus on the restoration of our planet. I hope this paper encourages readers to actively participate in the changes needed to save the planet. Are you ready? This article is a call for an active citizen participation to sow environmental conscience that derives in restoration actions of Mother Earth.

\section{REFERENCES}

ACOSTA, A. (2013). El Buen Vivir. Sumak Kawsay, una oportunidad para imaginar otros mundos. Barcelona: Icaria.

ARBOLEDA, I. \& PÁRAMO, P. (2014). La investigación en educación ambiental en América Latina: un análisis bibliométrico. Revista Colombiana de educación, v. 66, p. 55-72.

ASAMBLEA NACIONAL (2008). Constitución de la República del Ecuador. Quito: Asamblea Nacional.

BOWMAN, D., BALCH, J., ARTAXO, P., BOND, W., CARLSON, J., \& COCHRANE, C. (2009). Fire in the Earth System. Science, vol. 324, issue 5926, pp. 481-484.

CARSON, R. (1962). Silent Spring, New York: Houghton Mifflin.

CHRISTIAN, D. (2010). Mapas del tiempo. Introducción a la 'Gran Historia'. Barcelona: Crítica.

COLLADO, J. (2016). La huella socioecológica de la globalización. Sociedad y Ambiente, vol. 11, pp. 92121.

COLlADO, J. (2017). Educación Ambiental en Ecuador: reflexiones bioalfabetizadoras para el desarrollo sostenible. En: Martinez, M. (coord.) 
Visiones de Sostenibilidad. México DF: UASLP. pp. 307-326.

COLLADO, J. (2018). Co-evolution in Big History: A Transdisciplinary and Biomimetic Approach to the Sustainable Development Goals. Social Evolution \& History, vol. 17, n², pp. 27-41.

COLLADO, J. \& MALO, A. (2019). Biomimética y ciencias de la complejidad. Fundamentos para el desarrollo regenerativo. In: Re-descubriendo el mundo natural. La biomímesis en perspectiva. Colombia: UNAD. pp. 339-359.

DIAZ, R. (2013). Contexto Históico sobre el territorio y las ruinas arqueológicas de Ingapirca. https://www. researchgate.net/publication/325273764

FALCONÍ, F. (2014). Al sur de las decisiones: Enfrentando la crisis del siglo XXI. Quito: El Conejo.

FALCONÍ, F. (2017). Solidaridad sostenible: la codicia es indeseable. Quito: El Conejo.

GRININ, L., KOROTAYEV, A. \& RODRIGUE, B. (2011). Evolution: A Big History Perspective. Volgograd: Uchitel Publishing House.

INSTITUTO NACIONAL DE ESTADÍSTICA Y CENSO (INEC) (2010). Censo 2010. Población $y$ vivienda. Una historia para ver y sentir. Quito: INEC.

KELLERT, S. (2005). Building for Life: Designing and Understanding the Human-Nature Connection. Washington, DC: Island Press.

KRAINER, S. (coord.) (2012). Educación, interculturalidad y ambiente. Experiencias prácticas en centros educativos en Ecuador. Quito: FLACSO.

LEFF, E. (2002). Saber ambiental. Sustentabilidad, racionalidad, complejidad, poder. México: Editorial Siglo XXI.

LEGUÍA, J. \& PAREDES, N. (2016). Guía para docentes de cómo aplicar la metodología TiNi. Lima: ANIA.

MALO, A. (2015). El metabolismo social, el Sumak Kawsay y el territorio: el caso de Cuenca, Ecuador".
Tesis doctoral defendida en la Universidad Autónoma de Barcelona.

MIGNOLO, W. (2001). Capitalismo y geopolitica del conocimiento. El eurocentrismo y la filosofía de la liberación en el debate intelectual contemporáneo. Buenos Aires: El Signo.

Ministerio Coordinador del Patrimonio Humano (MCP) (2009). Plan Plurinacional para Eliminar la Discriminación Racial y la Exclusión Étnica $y$ Cultural 2009-2012. Quito: Ministerio Coordinador del Patrimonio Humano.

Ministerio de Ambiente del Ecuador (MAE) (2015). Quinto Informe Nacional para el Convenio sobre la Diversidad Biológica. Quito: MAE.

Ministerio de Educación del Ecuador (MinEduc) (2017). Guía Introductoria a la metodología TiNi. Tierra de niñas, niños y jóvenes para el Buen Vivir. Quito: Mineduc.

Ministerio de Educación del Ecuador (MinEduc) (2018a). Manual de Buenas Prácticas Ambientales para Instituciones Educativas. Quito: MinEduc.

Ministerio de Educación del Ecuador (MinEduc) (2018b). Memoria de sostenibilidad del Programa de Educación Ambiental "Tierra de Todos". Quito: MinEduc.

MÜLLER, E. (2018) Regenerative Development in Higher Education: Costa Rica's Perspective. In: Gleason N. (eds) Higher Education in the Era of the Fourth Industrial Revolution. Singapore: Palgrave Macmillan. https://doi.org/10.1007/978981-13-0194-0 6

NEAMAN, A.; OTTO, S. \& VINOKUR, E. (2018). Toward an Integrated Approach to Environmental and Prosocial Education. Sustainability, v. 10, n. 3, p. 583.

NICOLESCU, B. (2008). O Manifesto da Transdisciplinariedade. São Paulo: Triom.

ORR, D. (2002). The Nature of Desing. Ecology, culture, and human intention. Oxford: Oxford University Press. 
PAULI, G. (2015). La economía azul. 10 años, 100 innovaciones, 100 millones de empleos. Barcelona: Tusquets.

QUIJANO, A. (2000). Colonialidad del poder, eurocentrismo y América Latina. En E. Lander (comp.). La colonialidad del saber: Eurocentrismo y ciencias sociales. Perspectivas Latinoamericanas, pp. 201-246. Buenos Aires: CLACSO.

RIECHMANN, J. \& TICKNER, J. (coords) (2010). El principio de precaución. En medio ambiente y salud pública: De las definiciones a la práctica. Barcelona: Icaria.

SANTOS, B. (2010). Para além do pensamento abyssal: das linhas globais a uma ecologia de saberes. In: SANTOS, B. S. \& MENESES, M. P. (org.), Epistemologias do Sul. pp. 31-83. São Paulo: Cortez.

SCHUMACHER, E. (1973). Small Is Beautiful: A Study of Economics As If People Mattered. London: Blond and Briggs.

SIMON, F. (2013). Derechos de la naturaleza: ¿Innovación trascendental, retórica jurídica o proyecto político? Iuris Dictio. Revista del Colegio de Jurisprudencia de la Universidad San Francisco de Quito, 15, 9-38.

SPIER, F. (2011). El lugar del hombre en el cosmos. La Gran Historia y el futuro de la humanidad. Barcelona: Crítica.

STEFFEN, W., CRUTZEN, P. \& McNEILL, J. (2007). The Anthropocene: Are Humans Now Overwhelming the Great Forces of Nature? AMBIO: A Journal of the Human Environment, 36 (8): 614-621.

STIGLITZ, J., SEN, A. \& FITOUSSI, J. (2010). MisMeasuring Our Lives. Why GDP Doesn't Add Up. The report by the Commission on the Measurement of Economic Performance and Social Progress. New York: the new press.

TEITELBAUM, A. (1978). El papel de la educación ambiental en América Latina. París: UNESCO.
TORTOSA, J. M. (2009). Sumak Kawsay, Suma Qamaña, Buen Vivir. Madrid: Fundación Carolina.

UNESCO (1976).Seminario InternacionaldeEducación Ambiental. Informe final. Paris: UNESCO.

UNESCO (1978). Intergovernmental Conference on Environmental Education. Tbilisi (USSR). Final Report. Paris: UNESCO.

UNITED NATIONS (1987). Report of the World Commission on Environment and Develoment. "Our Common Future". General Assembly, New York: UN.

WACKERNAGEL, M. \& REES, W. (1996). Our Ecological Footprint. Reducing Human Impact on the Earth. Gabriola Island: New Society Publishers.

WAHL, D. (2016). Designing Regenerative Cultures. Axminster: Triarchy Press.

WALLERSTEIN, I. (1997). El futuro de la civilización capitalista. Barcelona: Icaria.

WALSH, C. (2009). Interculturalidad, estado, sociedad. Luchas (de) coloniales de nuestra época. Quito: UASB/Abya-Yala.

WASSILY, L. (1970). Environmental repercussions and the economic structure: an input-output approach. In: Review of Economics and Statistics, 52, pp. 262-271. 